\title{
Pemberdayaan Kreativitas Masyarakat Melalui Pembuatan Rindang (Risol Isi Ikan dan Udang) dan Kerupuk Ikan Bandeng di Desa Seuneubok Peusangan Kecamatan Peureulak Kabupaten Aceh Timur
}

\section{Haikal*1, Ellida Novita Lydia², Muhammad Haical ${ }^{3}$, Faiz Isma ${ }^{4}$, Okta Enjelin Sihite ${ }^{5}$, Yunika Indriani Silalahi6, Meilandy Purwandito ${ }^{7}$}

\author{
1,2,3,4,5,6,7 Teknik Sipil, Fakultas Teknik, Universitas Samudra, Indonesia \\ *e-mail: haikal2000h@gmail.com ${ }^{1}$, muhammadhaical720@gmail.com $^{3}$, oktasihite333@gmail.com $^{5}$, \\ yunikasilalahi30@gmail.com ${ }^{6}$
}

\begin{abstract}
Abstrak
Desa Seuneubok Peusangan merupakan salah satu desa yang terdapat di Kecamatan Peureulakyang memiliki potensi hasil tambak seperti udang dan ikan bandeng yang berlimpah dan menjadi sektor utama pada mata pencaharian masyarakat. Disini ingin memanfaatkan salah satu hasil tambak ikan bandeng dan udang yang akan diolah menjadi produk makanan cepat saji dan sangat praktis yaitu "Rindang dan Kerupuk" yang diminati semua kalangan terutama anak - anak yang sangat memerlukan gizi dari ikan dan udang. Kegiatan sosialisasi ini merupakan program kerja kelompok 23, dimana program ini merupakan salah satu sosialisasi yang melibatkan petani tambak di Desa Seuneubok Peusangan. Program ini bertujuan untuk memberikan serta meningkatkan potensi hasil laut yang ada di Desa Seuneubok Peusangan. Salah Satunya adalah dengan memberikan cara pengolahan ikan bandeng yang diolah menjadi sebuah produk makanan bertujuan untuk dapat meningkatkan perekonomian masyarakat yang ada di Desa Seuneubok Peusangan. Pada kegiatan ini, dilakukan metode yaitu dengan sosialisasi kepada masyarakat akan manfaat hadirnya produk baru untuk meningkatkan perekonomian dan kreativitas milik UMKN desa, dan praktek lapangan. Berdasarkan hasil sosialisasi tersebut, usaha ini sangat layak untuk dikembangkan karena antusiasnya masyarakat dalam pembuatan produk Rindang dan kerupuk bandeng serta dapat menjad peluang usaha yang berkelanjutan untuk meningkatkan perekonomian masyarakat dan desa tersebut. Serta dapat meningkatkan hasil produksi dari tambak udang dan bandeng.
\end{abstract}

Kata kunci: Ikan Bandeng dan Udang, Pemberdayaan Kreativitas Masyarakat, Pembuatan Rindang

\begin{abstract}
Seuneubok Peusangan Village is one of the villages located in Peureulak District which has the potential for pond yields such as abundant shrimp and milkfish and is the main sector of people's livelihoods. Here I want to take advantage of one of the results of milkfish and shrimp ponds which will be processed into fast food products and very practical, namely "Shady and Crackers" which are of interest to all people, especially children who really need nutrition from fish and shrimp. This socialization activity is a group work program of 23, where this program is one of the socialization activities involving pond farmers in Seuneubok Peusangan Village. This program aims to provide and increase the potential of marine products in Seuneubok Peusangan Village. One of them is by providing a way of processing milkfish which is processed into a food product with the aim of being able to improve the economy of the people in Seuneubok Peusangan Village. In this activity, the method is carried out, namely by socializing to the community the benefits of the presence of new products to improve the economy and creativity of the village UMKN, and field practice. Based on the results of the socialization, this business is very feasible to be developed because of the enthusiasm of the community in making leafy products and milkfish crackers and can become a sustainable business opportunity to improve the economy of the community and the village. And can increase the production of shrimp and milkfish ponds.
\end{abstract}

Keywords: Empowering Community Creativity, Making Rindang, Milkfish and Shrimp

\section{PENDAHULUAN}

Secara geografis Desa Seuneubok Peusangan terletak di Kecamatan Peureulak, Kabupaten Aceh Timur. Gampong ini berada jauh dari pusat ibu kota Banda Aceh dan terletak pada daerah jalur transportasi Banda Aceh-Medan. Gampong Seuneubok Peusangan memiliki 1.506 jiwa penduduk yang terdiri dari $\pm 370 \mathrm{KK}$. Gampong ini sudah mulai berkembang dalam hal memiliki 
akses sinyal khususnya sinyal internet, telepon, sudah adanya listrik sejak lama, memiliki rumah yang layak untuk dihuni, serta tidak terlalu jauh dari pusat kecamatan. Wilayah Gampong Seuneubok Peusangan berbatasan dengan beberapa gampong lainnya seperti di daerah barat berbatasan dengan Gampong Dama Tutong, sedangkan di daerah timur berbatasan dengan Gampong Seuneubok Pidie, pada daerah utara berbatasan dengan Gampong Matang Glem, dan pada daerah selatan berbatasan dengan Gampong Got Glintang. Desa Seuneubok Peusangan memiliki 4 dusun yaitu : Dusun Simpang Peut, Dusun Matang Beureuhoi, Dusun Krueng, Dusun Lampo Pala.

Secara umum meta pencaharian warga masyarakat Desa Seuneubok Peusangan terindentifikasi ke dalam beberapa sektor yaitu petani $40 \%$, nelayan $40 \%$, buruh $20 \%$, dan lainnya. Mayorias pekerjaan warga adalah petani tambak dan petani tambak dan nelayan. Karena banyak sekali tambak yang terlihat jika kita sudah masuk ke kawasan Desa Seuneubo Peusangan. Tetapi permasalahan yang umum terjadi di desa tersebut adalah pengelolaan sumber daya desa yang belum masksimal, hal tersebut perlu adanya usaha untuk mendukung kemajuan pengelolaan desa secara optimal. Salah satu hasil tambah yang paling banyak adalah udang dan ikan bandeng.

Kewirausahaan adalah seseorang yang memiliki kemampuan dalam menciptakan produk baru dan pasar baru yang disetai dengan keberanian serta mampu mengelola usaha yang pada akhirnya dapat menciptakan lapangan kerja melalui ide kreatif, inovatif, dan teroganisir tersebut. jiwa seorang wirausaha yaitu dapat mengambil resiko atas hasil mengambil resiko atas hasil ciptaannya dan melaksanakannya secara terbaik (ulet, gigih, tekun, progresif, dan pantang menyerah) sehingga nilai tambah yang diharapkan dapat dicapai. ikan bandeng dan undang merupakan jenis makanan laut yang paling banyak dibudidayakan di kawasan Aceh terutama Aceh Timur. Ikan bandeng dan udang memiliki daging yang enak dan lembut serta kandungan gizi yang tinggi sehingga sangat baik untuk dikonsumsi. Kedua jenis budidaya ini mempunyai prospek yang sangat baik karena banyak digemari oleh masyarakat. Hal ini disebabkan ikan bandeng memiliki beberapa keunggulan diantaranya memiliki rasa yang enak dan gurih, selain enak harga juga terjangkau oleh masyarakat.

Kerupuk ikan adalah produk makanan kering. Terbuat dari tepung, ikan, dan bahan lainnya suplemen lainnya. Ikan Bandeng (Chanos chanos) adalah ikan yang dapat digunakan untuk Pembuatan kue. C.chanos adalah ikan Kandungan nilai gizinya sangat bermanfaat tubuh manusia. Komposisi gizi daging C. chanos, seperti total lemak/asam lemak, protein/asam amino, dan mineral, dipengaruhi oleh beberapa faktor, yaitu: jenis kelamin, keadaan umum, stadium reproduksi, jenis pakan dan Kualitas lingkungan dan habitat. Misalnya, kandungan protein dan lemak C. chanos dari air payau lebih tinggi dari air tawa

Salah satu hasil makanan olahan dari udang yaitu Rindang ( risol ikan dan udang). Sedangkan hasil makanan olahan dari ikan bandeng adalah Kerupuk ikan bandeng. Produk yang dihasilkan mempunyai bentuk persegi, bau yang khas, awet dan mengandung protein yang tinggi. keunggulan ikan laut terutama bisa dilihat dari komposisi asam lemak Omega-3 yang bermanfaat untuk pencegahan penyakit jantung. Ada beberapa fungsi asal Omega-3. pertama dapat menurunkan kadar kolestrol darah yang berakibat terjadinya penyumbatan pembuluh darah. Kedua, manfaat lain dari lemak Omega-3 adalah berperan dalam proses tumbuh kembang otak. Pengolahan ikan dan udang dengan berbagai cara dan rasa menyebabkan orang mengkonsumsi ikan dan udang lebih banyak.

Selain rasa yang enak dan gurih dan di barengin dengan tingginya gizi dan vitamin. Anakanak, orang dewasa sampai lansia juga banyak yang mengemari makanan Rindang dan kerupuk bandeng ini. sehingga Program ini berbentuk indrustri kecil rumah tangga. Manfaat pengolahan ikan dan udang untuk waktu yang akan datang yaitu untuk meningkatkan kualitas ikan dan udang sehingga dapat dimanfaatkan dengan baik tanpa harus membuangnya dengan percuma. Alasan inilah maka ingin mengolah daging ikan menjadi Rindang dan kerupuk sehingga memiliki nilai ekonomis dan nilai protein yang lebih tinggi. Minimnya hasil diversifikasi olahan berbasis ikan dan masih rendahnya pengetahuan masyarakat desa mengenai usaha-usaha diversifikasi ikan dan udang 


\section{METODE}

Metode pelaksanaan adalah metode yang menggambarkan penguasaan penyelesaian pekerjaan yang sistematis dari awal sampai akhir meliputi tahapan/urutan pekerjaan utama dan uraian/cara kerja dari masing-masing jenis kegiatan pekerjaan utama yang dapat dipertanggungjawabkan secara teknis. Dalam penelitian ini akan dijelaskan mekanisme pembuatan Rindang dan kerupuk ikan bandeng di Desa Seuneubok Peusangan.

\subsection{Metodologi Pelaksanaan}

Dalam kesempatan ini, metodologi pelaksanaan yang digunakan pada KKN Tematik selama melaksanakan KKN di Desa Seuneubok Peusangan. Adapun metodologi pelaksanaan KKN Tematik di Desa Seuneubok Peusangan adalah sebagai berikut:

a. Survey tempat sosialisasi

Sebelum melakukan proses pembuatan, penulis terlebih dahulu melakukan survey tempat untuk mengadakan sosialisasi pembuatan produk.

b. Sosialisasi produk yang akan dibuat

Mengadakan sosialisasi kepada masyarakat di desa Seuneubok Peusangan tentang Rindang dan Kerupuk Ikan.

c. Proses Pembuatan

Setelah melakukan sosialisasi dan masyarakat pun menyetujui, maka mulai proses pembuatan nya.

\subsection{Waktu dan Tempat Kegiatan}

Pada kegiatan sosialisasi ini diadakan 2 kali pertemuan. hari pertama dilaksanakan pada tanggal 9 agustus 2021, dan hari kedua pada tanggal 11 agustus 2021. Hari pertama dilakukan sosialisasi bertempat pada aula kantor keuchik dan hari kedua pelatihan bertempat di lembaga kursus ratna taylor. Sosialisasi dan pelatihan tersebut ditargetkan untuk warga desa seuneubok pidie yang memiliki usaha menengah kebawah dan warga yang berminat untuk melakukan penjualan secara online.

\section{HASIL DAN PEMBAHASAN}

Desa Seuneubok Peusangan merupakan salah satu desa yang terdapat di Kecamatan Peureulak yang memiliki potensi hasil tambak seperti udang dan ikan bandeng yang berlimpah dan menjadi sektor utama pada mata pencaharian masyarakat. Kegiatan ini memanfaatkan shasil tambak ikan yaitu bandeng dan udang yang akan diolah menjadi produk makanan cepat saji dan sangat praktis yaitu "Rindang dan Kerupuk" yang diminati semua kalangan terutama anak - anak yang sangat memerlukan gizi dari ikan dan udang. Selain itu pengolahan produk ini juga bisa membantu meningkatkan perekonomian masyarakat didesa Seuneubok Peusangan.

Usaha ini sangat layak untuk direalisasikan karena mampu memberikan keuntungan dan dapat dilakukan secara berkelanjutan. Berikut kami sampaikan hasil pengamtan terhadap inovasi produk yang akan kembangkan.

a. Menjadi makanan cepat saji yang sangat digemari oleh semua kalangan.

b. Memudahkan dalam mengkonsumsi ikan dalam olahan yang berbeda.

c. Dapat menjadi bahan makanan yang dapat disimpan lama.

d. Dapat menginspirasi masyarakat setempat terutama wanita

Kegiatan pembuatan Rindang dan kerupuk merupakan program kerja kelompok 23, dimana program ini merupakan salah satu kegiatan kelompok KKN dan juga melibatkan aparatur desa setempat. Kegiatan ini kami lakukan agar mempermudah mencari lokasi daerah tersebut, dan untuk mengetahui perbatasan antar desa di Desa Seuneubok Peusangan.

Pada kegiatan sosialisasi ini diadakan 2 kali pertemuan atau selama 2 hari, hari pertama dilakukan sosialisasi dilaksanakan pada tanggal 9 agustus 2021. Sosialisasi ditargetkan untuk warga desa Seuneubok Peusangan yang memiliki usaha menengah kebawah dan berminat untuk 
melakukan penjualan secara online. Sosialisasi meningkatkan penjualan melalui strategi pemasaran online ini dilaksanakan pada aula kantor keuchik Seuneubok Peusangan dan dihadiri oleh 6 orang pemilik usaha menengah kebawah dan para peserta sangat antusias dalam mengikuti kegiatan ini.

Materi sosialisasinya disampaikan oleh mahasiswa yang berasal dari prodi Teknik industri. Mahasiswa menjelaskan terkait cara melakukan iklan di sosial media seperti Instagram ads, cara menggunakan website dalam melakukan penjualan, dan juga cara penggunaan Platform Marketplace yang tersedia seperti Shopee dan Tokopedia dan yang terakhir mengenai cara untuk menarik minat beli dari sosial media. Tujuan kegiatan sosialisasi ini adalah sebagai implementasi dari pelaksanaan Tri Dharma Perguruan Tinggi dan mendekatkan Perguruan Tinggi kepada masyarakat serta diharapkan para peserta sosialisasi tertarik untuk melakukan penjualan secara online di era digital ini.

Kegiatan kedua yaitu pelatihan membuat foto produk dilaksanakan pada Tanggal 11 Agustus 2021. Pelatihan ini ditargetkan untuk warga Desa Seuneubok Peusangan khususnya pemilik usaha dan yang berhadir pada hari tersebut sebanyak 6 orang. Pelatihan dilakukan di lembaga kursus dan pelatihan ratna taylor dengan warga yang memiliki UMKM dan usaha jualan online. Metode dalam pelaksanaaan kegiatan ini mengutamakan keaktifan peserta KKN untuk mengolah dan menciptakan Brand produk serta mengajarkannya pada pelaku UMKM terkait.

Pelatihan meliputi pelatihan pembuatan logo usaha, pelatihan pembuatan katalog penjualan yang menarik, dan pelatihan membuat video review produk yang menarik. Tujuan kegiatan ini adalah untuk membuat para pelaku UMKM dapat meningkatkan profit penjualan baik dari penjualan secara offline maupun online.

Monitoring dan evaluasi dilakukan untuk mengetahui kemajuan pelaksanaan kegiatan dan menilai kesesuaian kegiatan yang telah dilakukan dengan yang direncanakan. Evaluator dapat terdiri dari kelompok-kelompok kecil. Asesor juga menjadi motivator bagi pengelola dan panelis untuk menambah pengetahuan tentang pengelolaan kerupuk bandeng. Hasil yang dicapai yakni respon para masyarakat sangatbaik, dan mereka mau mencoba untuk membuat kerupuk bandeng dan mencoba untuk menjualnya. Ada juga beberapa masyarakatyangsudah menerapkannya namun masih belum sempurna. Adapun untuk tindak lanjut dari kegiatan utama ini adalah diharapkan kedepannya mereka tetap konsisten dalam menjalankan pengimplementasian krupuk bandeng dankeuntungannya bisa mereka rasakan sendiri.

Kegiatan ini dilakukan untuk pembuatan desain logo produk atau re-branding produk UMKM sesuai keinginan pemilik UMKM. Setelah pembuatan desain tersebut selesai, lalu mahasiswa melanjutkan kegiatan pembuatan foto produk dan video produk yang kekinian dan nantinya foto tersebut akan diunggah ke e-commerce dan sosial media. Kegiatan tersebut berlangsung sangat kooperatif dan saling berbagi ilmu antara pemilik UMKM dengan mahasiswa KKNT.

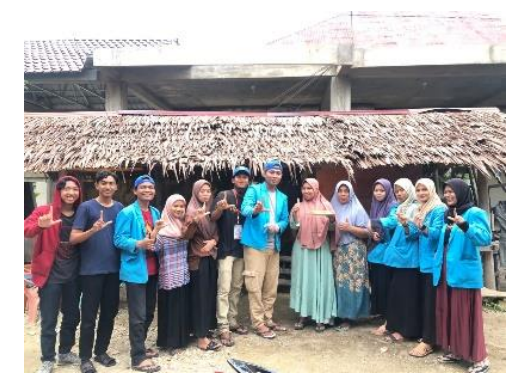

Gambar 1. Foto bersama setelah Sosialisasi Pembuatan Rindang

Faktor pendukung terlaksananya kegiatan ini dengan baik antara lain:

a. Dukungan dari perangkat desa Seuneubok Peusangan.

b. Dukungan dari anggota kelompok $23 \mathrm{KKN}$-Tematik.

c. Kesediaan Warga dan pemilik UMKM desa Seuneubok Peusangan.

Faktor penghambat terlaksananya kegiatan ini dengan baik yaitu kurangnya minat warga terhadap penggunaan website $E$-commerce. 


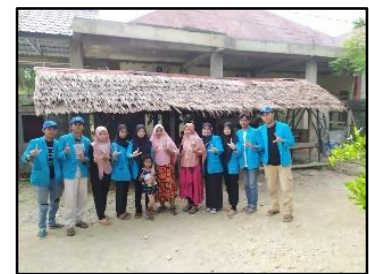

(a)

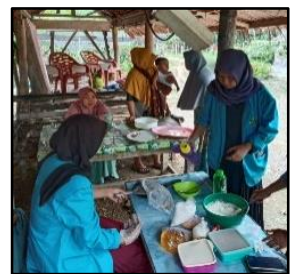

(b)

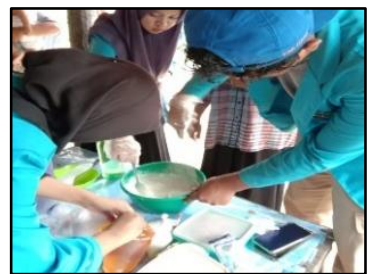

(c)

Gambar 2. (a) Foto bersama setelah Sosialisasi Pembuatan Kerupuk Ikan Bandeng. (b) Proses Pembuatan Rindang saat sosialisasi. (c) Proses Pembuatan Kerupuk Ikan Bandeng saat sosialisasi.

\section{KESIMPULAN}

Masyarakat di Desa Seuneubok Peusangan ini pada dasarnya memiliki pendapatan ekonomi kelas menenggah kebawah hal itu dilihat dari pekerjaan dan warga desanya, hal tersebut semakin diperparah dengan kurangnya kesadaran masyarakat untuk menciptakan suatu produk yang baru. Maka dari itu kegiatan sosialisasi bagi masyarakat desa Seuneubok Peusangan untuk meningkatkan perekonomian, dan menciptakan suatu produk baru hingga dapat menciptakan lapangan pekerjaan yang baru yaitu Rindang (risol ikan dan udang) dan kerupuk ikan bandeng. Sehingga semua masyarakat dapat merasakan manfaatnya dari adanya kegiatan KKN di desa tersebut. Serta dapat menambah pengetahuan dan wawasan tentang Pemasaran, sehingga dapat mengimplementasikan berbagai strategi pemasaran, sehingga omzet penjualan meningkat. Dengan demikian, maka dapat meningkatkan potensi lokal yang dimiliki oleh paramitra.

\section{SARAN}

1. Kepada pihak desa diharapkan lebih peduli terhadap masyarakat terutama sumberdaya yang ada di desa karanggeneng yang akan dijadikan sebuah usaha atau bisnis.

2. Kepada mahasiswa KKN selanjutnya, disarankan sebagai berikut: Agar program sosialisasi implementasiini tetap dilanjutkandan dikembangkan

3. Memberikan pelayanan pelanggan melalui sistem terintegrasi dengan media sosial untuk memberikan informasi yang

\section{UCAPAN TERIMA KASIH}

Terimakasih penulis ucapkan kepada Kepala Desa Seunebok Peusangan yang telah menerima untuk mealukan kegiatan tersebut, kemudian kepada rekan-rekan yang terlibat dalam kegiatan ini.

\section{DAFTAR PUSTAKA}

23, K. (2021). Laporan Kuliah Kerja Nyata (KKN) Tematik "Pengolahan Hasil Laur di Industri Pesisir" Kabupaten Aceh Timur. 1-40.

Andi Rahmad Rahim, N. D. (2019). Sosialisasi Dan Implementasi Pembuatan Krupuk Ikan Bandeng Desa Karanggeneng Kec. Karanggeneng Kab. Lamongan. Journal of Community Service, 1-10.

Oktaviola, R. D. (2020). Kuliah Kerja Nyata (KKN) Tematik Membudayakan Hidup Sehat bagi Anak-anak untuk Mencegah Penyebaran Covid-19 di Desa Ngilaman Kabupaten Sawahan Kecamatan Nganjuk. 1-7.

Teknik, F. (2021). Buku Pedoman Kuliah Kerja Nyata (KKN) Tematik "Kontribusi Fakultas Teknik Dalam Pengembangan Industri Pesisir (Minapolitan) Kabupaten Aceh Timur. Langsa: Fakultas Teknik Universitas Samudra. 


\section{Halaman Ini Dikosongkan}

